\title{
Organizing the Tourism Line from Chenar Village to Tar Lake of Damavand, Iran
}

\author{
Azita Rajabi \\ Senior Lecturer and Faculty Member, Tehran Center Branch \\ Islamic Azad University, Tehran, Iran \\ Taraneh Sanei (Corresponding author) \\ Master in Tourism Planning \& On Geography, Department of Geography \\ Faculty of Literature \& Humanity Sciences, Tehran Center Branch \\ Islamic Azad University, Tehran, Iran \\ E-mail: tsaniei@yahoo.com
}

Received: September 30, $2011 \quad$ Accepted: October 15, $2011 \quad$ Published: March 1, 2012

doi:10.5539/ass.v8n3p246

URL: http://dx.doi.org/10.5539/ass.v8n3p246

\begin{abstract}
This article deals with organizing the tourism line from Chenar Village to Tar Lake of Damavand, Iran. In order to achieve the research objectives, the survey method (with purposes of description and exploration) and descriptive-analytic method were applied by reviewing and analyzing the economic, social, cultural and environmental effects in East Chenar village to the lake of Tar. The population of this study includes three groups of rural households living in the East Chenar Village, tourists who are traveling to the region and officials of relevant organizations and institutions. The research showed that by organizing the tourism aspect of Chenar village to Tr lake, the development in this region can be acheived.
\end{abstract}

Keywords: Tourism, Organizing, Chenar village, Lake of Tar, Damavand, Iran

\section{Introduction}

Tourism has been one of the world's fastest growing industries, and there are large societies entirely dependent upon the visitor for their sustenance (Note 1). Tourism is the world's largest industry. It sustained 120 million jobs in 1995 , accounting for $7 \%$ of the global workforce. It is estimated that the number of international travelers in 1994 will double to 1 billion by 2010, and $80 \%$ of tourists come from the 20 richest countries (The Hutchinson Encyclopedia).

The impact of tourism is extremely varied. On one hand, it plays an important and certainly positive role in the socio-economic and political development in destination countries by, for instance, offering new employment opportunities. Also, in certain instances, it may contribute to a broader cultural understanding by creating awareness, respecting the diversity of cultures and ways of life. On the other hand, as a tool to create jobs, it has not fulfilled its expectations. At the same time, complaints from tourist destinations concerning massive negative impacts upon environment, culture and residents' ways of life have given rise to a demand for a more sustainable development in tourism (Note 2).

According to the records from WTO, tourism industry in the early years of the $21^{\text {st }}$ century has had a remarkable growth and accelerated so fast that it has surpasses many other economics sectors of the human communities. The improvements in people's income and culture, the increase in the world population as whole, enhanced developments in the latest transportation technology, an increase in the leisure time and natural propensity of human being to travel around have made many countries to bring this industry in their focal point and develop it as far as they can.

According to statistics, about 922 million people crossed international boundaries in the year 2008 and created a wealth of approximately \$ 944 billion. It is predicted that in 2020 some 1600 million people will be traveling to 
different countries as tourists (or pilgrims) and, as estimated, the revenues gained globally in the same year will mount up to about $\$ 2000$ billion. This giant tree will take roots in the farthest gardens of the most remote villages, rough mountain passes, heart of the forests and meadows. Some countries do not have oil/gas reserves, metals and mineral but their revenue tourism would outstrip those countries who have such God-given gifts (Tohidy Ardahaey, 2011).

Tourism is not an industry per se but a collection of interrelated industries, which sell products to tourists as well as to a range of other customers: hotels, tour operators and travel agents, airlines, etc.

Tourism consumption usually leads to increased output, prices and wages in the industries that sell products directly to tourists. Therefore, poor households are likely to be negatively affected via the price channel; rising price will reduce the real income effect. The largest increases in prices that result are, in general, for the types of goods and services that tourists consume. These are products that domestic residents only usually consume if they take a trip (accommodation, passenger transport, tour agency and operation services, recreational services, and souvenir goods), if they go to restaurants or if they buy food products. Most products are those purchased more by higher income households; the direct effect of the channel will lead to small increases in prices paid by poor households, through food products. Even in this case, tourists tend to buy a different set of food from those consumed by poor Households (Laffargue, 2009; Tohidy Ardahaey, 2011).

A standard economic impact analysis traces flows of money from tourism spending, first to businesses and government agencies where tourists spend their money and then to other businesses -- supplying goods and services to tourist businesses, households - earning income by working in tourism or supporting industries, and government -- through various taxes and charges on tourists, businesses and households (Stynes, 1997). These effects are generally considered as direct, indirect and induced which are introduced as follows.

Direct effects are production changes associated with the immediate effects of changes in tourism expenditures. For example, an increase in the number of tourists staying overnight in hotels would directly yield increased sales in the hotel sector. The additional hotel sales and associated changes in hotel payments for wages and salaries, taxes, and supplies and services are direct effects of the tourist spending.

Indirect effects are the production changes resulting from various rounds of re-spending of the hotel industry's receipts in other backward-linked industries (i.e., industries supplying products and services to hotels). Changes in sales, jobs, and income in the linen supply industry, for example, represent indirect effects of changes in hotel sales. Businesses supplying products and services to the linen supply industry represent another round of indirect effects, eventually linking hotels to varying degrees to many other economic sectors in the region.

Induced effects are the changes in economic activity resulting from household spending of income earned directly or indirectly as a result of tourism spending. For example, hotel and linen supply employees, supported directly or indirectly by tourism, spend their income in the local region for housing, food, transportation, and the usual array of household product and service needs. The sales, income, and jobs that result from household spending of added wage, salary, or proprietor's income are induced effects.

By means of indirect and induced effects, changes in tourist spending can impact virtually every sector of the economy in one way or another. The magnitude of secondary effects depends on the propensity of businesses and households in the region to purchase goods and services from local suppliers. Induced effects are particularly noticed when a large employer in a region closes a plant. Not only are supporting industries (indirect effects) hurt, but the entire local economy suffers due to the reduction in household income within the region. Retail stores close and leakages of money from the region increase as consumers go outside the region for more and more goods and services. Similar effects in the opposite direction are observed when there is a significant increase in jobs and household income (Stynes, 1997).

Thus, considering the direct, indirect positive and negative economic impacts of tourism industry, one could realize that with short-term and long-term strategic planning and using the specific abilities and tourism products of developing countries, which suffer from some indices as unemployment, limits in earning and currency flows, inflation and other problems, most of their economic problems can be solved (Tohidy Ardahaey, 2011).

This study focuses on organizing the dimension of tourism considering Chenar village to Tar lake of Damavand, Iran as a touristic zone aiming to deal with the local residents of East Chenar.

\section{Industrial tourism}

Industrial tourism is a relatively unexplored research theme, with a lack of clear concepts and definitions. First, the term industrial tourism has different meanings. Particularly in the US, some use the term industrial tourism when they talk about a commercial approach to tourism, maximising the return on investment (for example 
Wemhaner, 1976). From this point of view, industrial tourism implies the marketing of tourism as a commodity to be sold for mass consumption.

Industrial tourism is a type of tourism which involves visits to operational companies and industrial heritage; it offers visitors an experience with regard to products, production processes, applications, and historical backgrounds. More than 100 years ago public and private organisations already started to organise industrial tourism visits. Historic examples include visits to French wineries and chocolate factories, to Greek and Maltese lace-producers and to Dutch cheese producers. In Paris, tourists and residents had the opportunity to choose among various tours back in 1900. The tours on offer ranged from visits of textile-factories to tours of mortuaries and slaughterhouses. Furthermore, also a visit to a tobacco factory, the stock exchange, the parliament and the court of justice were possible. There is also evidence from the United States that industrial tourism has actually a long history; a good example is the Jack Daniel's distillery in Tennessee which

began to offer factory tours back in 1866, the year when the company started operating (Frew, 2000).

Industrial tourism offers opportunities for individual firms, but also for cities. Particularly for cities with a considerable industrial base, industrial tourism comprises interesting possibilities to strengthen the economic structure (direct and indirect employment) and to increase the supply of tourist products. For such cities industrial tourism is a potential growth sector that matches with their identity: the sector offers opportunities to strengthen their distinctiveness and image, notably by building on their existing assets. Many cities, however, have the assets to develop industrial tourism but fail to capitalise on them. In most cases industrial tourism is only restricted to low-profile company visits, without any clear vision of the municipality or firm on the strategic value of it, not tomention coordinated product development.

The development of industrial tourism largely depends on the ability of firms to cooperate. On the one hand, we observe that many firms consider company tours an obligation with more costs than revenues. Many companies are afraid of leaking confidential business information, and also security often constitutes a problem. On the other hand, more and more companies also recognise the opportunities of industrial tourism: industrial tourism can help to market their product, to secure their license to operate (reputation), and to remain attractive as employer.

\section{Organizing the tourism}

Organizing approach to tourism in the village of Chenar to Lake of Tar shows the linkage of different components of the tourism system. This tourism system in its positive and negative feedback has led to much influence in a general framework on the environment, tourists and the host community. However, the tourist flow in this line hass been formed without planning and interference from government or local institutions and organizations. The tourism flow in this line has emerged based on the tourists' demand on passing their leisure time and their other requirements. So, obviously planning on organizing tourism in this line requires initially the study of their needs. Meanwhile, the development of tourism in the region is studied in three dimensions of tourists, environment and the government, the adaption of the two aspects of tourists and environment provides the necessary strategies to develop tourism and function of the government and the local officials. This of cource requires in organizing the tourism industry to meet all deficiencies and defects of the organization by local officials aiming to optimize the tourism flow in the region.

\section{Research goals}

4.1 Main goal

Identifying the advantages of organizing the tourism line from Chenar Village to Tar Lake of Damavand, Iran

4.2 Sub-goals

1. Identifying the economic effects of tourism in East Chenar village to the lake of Tar

12. Identifying the social effects of tourism in East Chenar village to the lake of Tar

13. Identifying the cultural effects of tourism in East Chenar village to the lake of Tar

14. Identifying the environmental effects of tourism in East Chenar village to the lake of Tar.

\section{Research hypothesis}

It seems that by organizing the tourism aspect of Chenar village to Tar lake, the development in this region can be acheived. 


\section{Research Methodology}

In order to achieve the research objectives, the survey method (with purposes of description and exploration) and and descriptive-analytic method were applied by reviewing and analyzing the economic, social, cultural and environmental effects in East Chenar village to the lake of Tar.

\section{Statistical population and sample}

The population of this study includes three groups of rural households living in the East Chenar Village, tourists who are traveling to the region and officials of relevant organizations and institutions.

The population of East Chenar Village is 330 people including 93 families from among which, 75 households were selected as the statistical sample interviewing the heads of the families.

For selecting some samples from among tourists in the region, the number of the tourists visiting the region during a summer week was estimated and 50 people of them selected from the average of the number.

Because of the small number of the officials, it was tried to prepared questionnaires for all of them.

\section{Data collection methods and tools}

The data in this study was collected by using methods of field, library, surveys and interview with people, tourists and officials. For this purpose, direct contact with statistical centers, using rural plans, maps and pictures and also preparing questionnaires, interview and field study helped to complete the data collection process.

\section{Data analysis methods}

In this study to evaluate the information and to analyze the questionnaires, statistical techniques have been used as follows:

1 - Cronbach's alpha coefficient to assess reliability of the questionnaires.

2 - Other statistical techniques that are used based on the need and necessity.

\section{The study area}

The region of village of East Chenar to the lake of Tar is located in the central city of Damavand. This village is located $3 \mathrm{~km}$ distant from the city of Damavand. The tourism line of the village to the Lake of Tar is located in the northeastern part of the city of Damavand.

this region due being blocked, owns specific characteristics. It lies from the north to the Basin area of Haraz, from the west to the river of Damavand, from the south to the Basin of Eyvanaki and from the east it leads to the Delichay resource.

Its minimum and maximum altitudes are 2500 meters is 4072 meters. Also, the main part of the slope is in the floor area of 56 to 30 percent.

Minimum and maximum altitude of 2500 meters is 4072 meters.

\section{The touristic attractions of the region}

The most important attractions in the study area are described in the table below:

$<$ Insert Table 1 here $>$

\section{Conclusion}

No doubt that tourism can play an important role in revitalizing economies in rural communities. At the same time, tourism can serve as a means for maintaining and revitalizing rural environments and thus, no wonder that in most countries it is considered as a solution for most rural problems.

This is generally accepted that within a very wide range of tourism activities and its sub-sectors such as transportation, accommodations, attractions, entertaining, relaxing and other similar activities it needs a proper organizing and by strategic and long-term planning and management especially in the studied region, the conditions for optimizing the tourist interests and reducing the costs and negative affects on the ecosystem of the host community should be provided. Also, the local public contribution, cooperation of all related people and organizations and effective management of the visitors in the region are of the basic components of the process of suitable plannining and management in the touristic region. 


\section{References}

Frew, E.A. (2000). Industrial Tourism: a conceptual and empirical analysis. PhD Thesis, Victoria University.

Industrial Tourism Development in Cities:Towards a Framework. [Online] Available: http://www.ashgate.com/pdf/SamplePages/Industrial_Tourism_Ch1.pdf

Laffargue J. P. (2009). The economic and social effects of tourism activities and tourism policies. A survey of the computable general equilibrium (CGE) models approach, CEPREMAP, Version septembre 2009, Docweb no 0905.

Stynes, D. J. (1997). Economic Impacts of Tourism, A Handbook for Tourism Professionals, Illinois Bureau of Tourism, Illinois Department of Commerce and Community Affairs, Prepared by the Tourism Research Laboratory at the University of Illinois at Urbana-Champaign, Fall, 1997. [Online] Available: http://150.214.182.12:8080/turismo/turismonet1/economia\%20del\%20turismo/economia\%20del\%20turismo/eco nomic\%20impacts\%20of\%20tourism.pdf

The Hutchinson Encyclopedia.

Tohidy Ardahaey, Fateme. (2011). Economic Impacts of Tourism Industry. International Journal of Business and Management, Vol. 6, No. 8, August.

Tohidy Ardahaey, Fateme. (2011). Obstacles impeding the development of tourism industry in Iran with emphasis on marketing. Elixir Tourism Mgmt, 36, 3045-3054.

[Online] Available: http://planningcommission.nic.in/plans/stateplan/sdr_hp/sdr_hpch19.pdf

[Online] Available: http://www.un.org/esa/sustdev/csd/ngo4.pdf

Notes

Note 1. http://planningcommission.nic.in/plans/stateplan/sdr_hp/sdr_hpch19.pdf

Note 2. http://www.un.org/esa/sustdev/csd/ngo4.pdf

Table 1. Touristic attractions line of Chenar village to the lake of Tar in Damavand

\begin{tabular}{|c|c|c|c|}
\hline & $\begin{array}{l}\text { Type of } \\
\text { attraction }\end{array}$ & Name & Location \\
\hline 1 & Natural & Gardens and farms & $\begin{array}{l}\text { Village of East } \\
\text { Chenar }\end{array}$ \\
\hline \multirow[t]{6}{*}{2} & \multirow{6}{*}{ Natural } & Mt Mianroud: 3650 meters high & \multirow{6}{*}{ Altitudes } \\
\hline & & Mt Golezard: 3693 meters high. & \\
\hline & & $\begin{array}{l}\text { Mt Qaredagh (Angmar): } 4076 \\
\text { meters high. }\end{array}$ & \\
\hline & & Mt Zarinkouh: 3850 meters high. & \\
\hline & & Mt Dubrar (maz): 4250 meters high. & \\
\hline & & $\begin{array}{l}\text { Mt Changizchal (Bazmchal): } 4010 \\
\text { meters high. }\end{array}$ & \\
\hline \multirow[t]{3}{*}{3} & \multirow{3}{*}{ Natural } & Damavand River & \multirow{3}{*}{ Rivers } \\
\hline & & Black River & \\
\hline & & Tar River & \\
\hline \multirow[t]{2}{*}{4} & \multirow{2}{*}{ Natural } & Lake Tar & \multirow{2}{*}{ Lakes } \\
\hline & & Lake Hoveyr & \\
\hline 5 & Natural & Damavand summit & Perspectives \\
\hline 6 & Natural & $\begin{array}{l}\text { vegetation and rare plants and rare } \\
\text { medicinal herbs and edible }\end{array}$ & Flora \\
\hline 7 & Natural & $\begin{array}{l}\text { Species of animal life, reptiles, } \\
\text { rodents, birds, mammals and } \\
\text { aquatic }\end{array}$ & Fauna \\
\hline
\end{tabular}

